\title{
Synthesis of optically active 1,5-benzothiazepines
}

\author{
Albert Lévai* and Attila Kiss-Szikszai \\ Department of Organic Chemistry, University of Debrecen, P.O.Box 20, H 4010 Debrecen, \\ Hungary \\ E-mail: alevai@puma.unideb.hu
}

Dedicated to Professor Nina Berova on the occasion of her $70^{\text {th }}$ birthday

\begin{abstract}
Optically active 1,5-benzothiazepines belong to the well known benzothiazepine type substances. Some of them possess important bioactivities. In this review article, optically active 2,3-dihydro1,5-benzothiazepin-4(5H)-ones, their 3-amino and 3-hydroxy derivatives, comprising the most important groups of these benzothiazepines, will be discussed in detail. Less known optically active 1,5-benzothiazepines will also be included.
\end{abstract}

Keywords: 2,3-Dihydro-1,5-benzothiazepin-4(5H)-ones, 3-alkyl-2,3-dihydro-1,5-benzothiazepin-4(5H)-ones, 3-amino-2,3-dihydro-1,5-benzothiazepin-4(5H)-ones, 2,3-dihydro-3-hydroxy1,5-benzothiazepin-4(5H)-ones

\section{Contents}

1. Introduction

2. Synthesis and Stereochemistry of Optically Active 2,3-Dihydro-1,5-benzothiazepin-4(5H)ones Substituted at Position 2

3. Synthesis of Optically Active 3-alkyl-2,3-dihydro-1,5-benzothiazepin-4-(5H)-ones

4. Synthesis and Bioactivities of Optically Active 3-Amino-2,3-dihydro-1,5-benzothiazepin$4(5 H)$-ones

5. Synthesis and Bioactivities of Optically Active 2,3-Dihydro-3-hydroxy-1,5-benzothiazepin$4(5 H)$-ones

6. Miscellaneous

7. Conclusions 


\section{Introduction}

The 1,5-benzothiazepine is one of the three possible benzocondensed derivatives, viz. 1,4-, 4,1and 1,5-benzothiazepines of the 1,4-thiazepine. ${ }^{1}$ The parent 1,5-benzothiazepine has not yet been published in the chemical literature, but its derivatives are the most frequently investigated benzothiazepine type compounds. 2,3-Dihydro-1,5-benzothiazepin-4(5H)-ones are especially popular substances since they possess wide range of bioactivities. Therefore, the 1,5benzothiazepines are useful compounds in the drug research which has stimulated the invention of a wide range of synthetic methods for their preparation and chemical transformations. This is due for the synthesis of optically active 1,5-benzothiazepines as well.

The major aim of this review is to provide examples for the synthesis of the known groups of the optically active 1,5-benzothiazepines. In some cases, the stereochemical studies of the synthesized new compounds are included. Their most important bioactivities will also be discussed together with the synthesis of special groups of substances.

\section{Synthesis and Stereochemistry of Optically Active 2,3-Dihydro-1,5- benzothiazepin-4(5H)-ones Substituted at Position 2}

The first representatives of the optically active 1,5-benzothiazepines were the enantiomers of the 2-(carboxymethyl)-2,3-dihydro-1,5-benzothiazepin-4(5H)-one (3). Racemic 3 was prepared by the heating of a mixture of 2-aminothiophenol (1) and glutaconic acid (2). Resolution of this racemate with brucine provided the (+)-3 and (-)-3 enantiomers ${ }^{2}$ (Scheme 1). Since this work was published as early as 1927, absolute configuration data are not mentioned in this paper. This was the sole example for the preparation of optically active benzothiazepines for four decades.

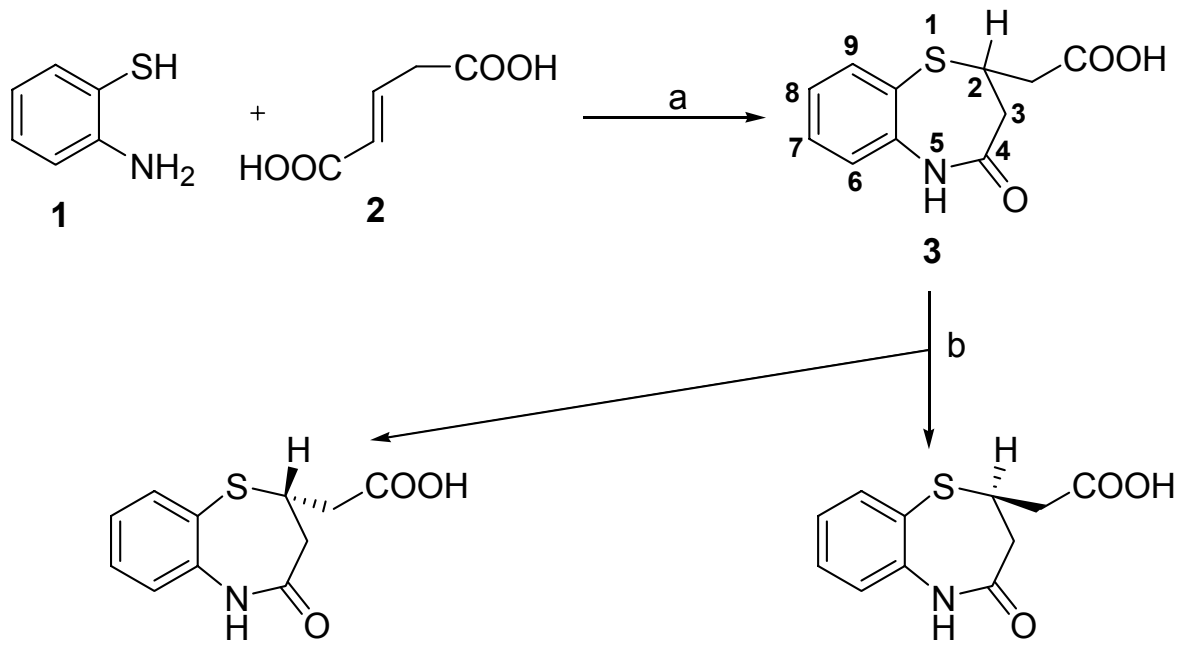

Scheme 1. (a) heating at $120-130{ }^{\circ} \mathrm{C}$ for $20 \mathrm{~min}$; (b) brucine, dilute $\mathrm{HCl}^{2}$ 
The next communication was the optical resolution of the 2,3-dihydro-5-[2(dimethylamino)ethyl]-2-phenyl-1,5-benzothiazepin-4(5H)-one (thiazesim) with $(+)$-tartaric acid in $1968 .^{3}$ A common feature of these two examples is that 1,5 -benzothiazepines with a functional group capable of salt formation were synthesized as racemates. Optical resolution of these racemates provided the appropriate optically active 1,5-benzothiazepine enantiomers.

For the synthesis of optically active 2,3-dihydro-1,5-benzothiazepin-4(5H)-ones substituted at position 2 a retrosynthetic approach was invented by Lévai et al. ${ }^{4}$ This retrosynthetic approach enabled the first synthesis of optically active 2,3-dihydro-1,5-benzothiazepin-4(5H)-ones without functional groups capable of salt formation. Racemic nitrocarboxylic acids $\mathbf{4}$ and $\mathbf{5}^{5}$ were used as starting materials. Brucine salts of compounds $\mathbf{4}$ and $\mathbf{5}$ were crystallized from ethanol until each salt showed constant optical rotation, then the diastereomeric salts were decomposed with dilute hydrochloric acid to afford optically active nitrocarboxylic acid enantiomers. Optically active nitrocarboxylic acids were reduced to the appropriate aminocarboxylic acids 6 and 7 on treatment with $\mathrm{Zn}$ powder in acetic acid. Optically active 2,3-dihydro-1,5-benzothiazepin-4(5H)ones 8 and 9 were obtained by the ring closure of the optically active aminocarboxylic acids 6 and 7 in boiling xylene ${ }^{4}$ (Scheme 2).

Conformation of the seven-membered ring was determined by NMR spectroscopy. ${ }^{6}$ Absolute configuration of the centre of chirality of these optically active 2,3-dihydro-1,5-benzothiazepin$4(5 H)$-ones $(\mathbf{8 , 9})$ and their optically active intermediates were elucidated by a combined utilization of X-ray diffraction analysis and circular dichroism (CD) spectroscopic measurements. ${ }^{7,8}$ 


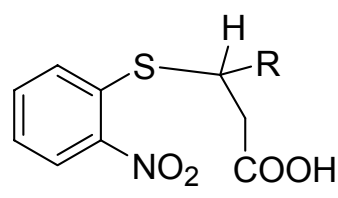

$(R, S) \mathbf{4 , 5}$

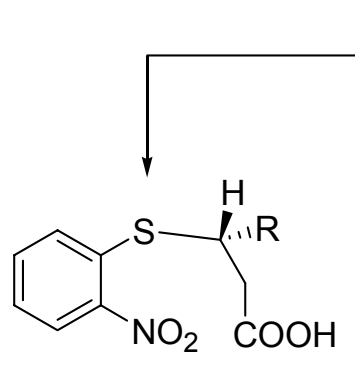

4: $\mathrm{R}=\mathrm{Me}(R)$

5: $\mathrm{R}=\mathrm{Ph}(S)$

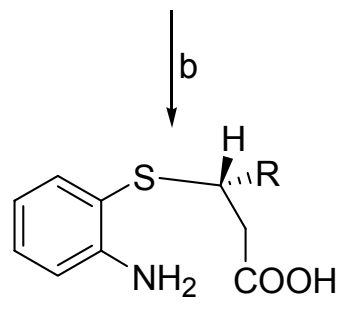

6: $\mathrm{R}=\mathrm{Me}(R)$

7: $\mathrm{R}=\mathrm{Ph}(S)$

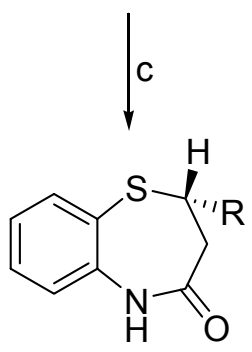

8: $\mathrm{R}=\mathrm{Me}(R)$

9: $\mathrm{R}=\mathrm{Ph}(S)$

|a

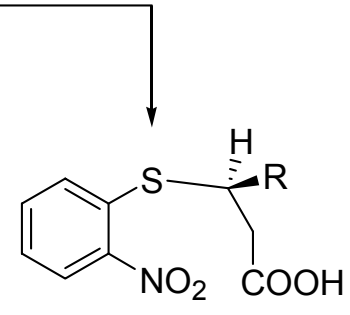

4: $\mathrm{R}=\mathrm{Me}(S)$

5: $\mathrm{R}=\mathrm{Ph}(R)$

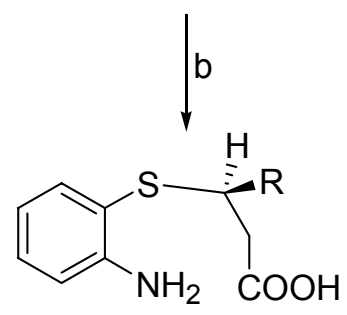

6: $\mathrm{R}=\mathrm{Me}(S)$

7: $\mathrm{R}=\mathrm{Ph}(R)$

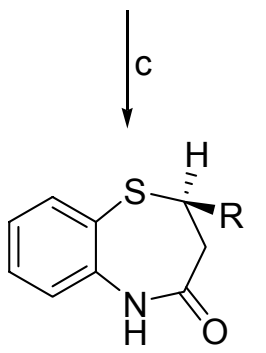

8: $\mathrm{R}=\mathrm{Me}(S)$

9: $\mathrm{R}=\mathrm{Ph}(R)$

Scheme 2. (a) brucine, $\mathrm{HCl}$; (b) Zn powder, $\mathrm{MeCOOH}$; (c) boiling xylene. ${ }^{4}$

2,3-Dihydro-1,5-benzothiazepin-4(5H)-ones substituted at position 2 can also be prepared by the ring enlargements of 1-thiochromanones. ${ }^{9}$ Either the Schmidt reaction of 1thiochromanones ${ }^{10}$ or the Beckmann rearrangement of their oximes ${ }^{11}$ can be utilized for this purpose. Dike et al. synthesized $(R)$-2,3-dihydro-2-methyl-1,5-benzothiazepin-4(5H)-one $[(R)-8]$ by the Beckmann rearrangement of the $(R)$-2-methyl-1-thiochromanone $[(R)-10]^{12}$ and $(R)-2,3$ dihydro-2-phenyl-1,5-benzothiazepin-4(5H)-one [(R)-9] also by the Beckmann rearrangement $(R)$-2-phenyl-1-thiochromanone $[(R)-11]^{13}$ (Scheme 3). $N$-Alkylation of compound $(R)-9$ with 2(dimethylamino)ethyl chloride provided $(R)$-thiazesim $[(R)-12]$ which was the first optically 
active 1,5-benzothiazepine with known bioactivity since it was found to exhibit central nervous system activity. ${ }^{3,13}$<smiles>C[C@H]1C/C(=N\O)c2ccccc2S1</smiles>

$(R)-10$<smiles>C[C@H]1CC(=O)Nc2ccccc2S[C@H]1C</smiles>

(R)-8<smiles>O/N=C1\C[C@H](c2ccccc2)Sc2ccccc21</smiles>

(R)-11<smiles>O=C1C[C@H](c2ccccc2)[C@H](I)C[C@@H]1c1ccccc1</smiles>

(R)-9

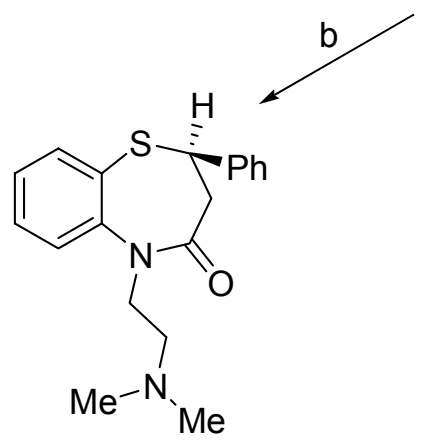

$(R)-12$

Scheme 3. (a) PPA, $120{ }^{\circ} \mathrm{C}, 2 \mathrm{~h}$; (b) $\mathrm{Cl}\left(\mathrm{CH}_{2}\right)_{2} \mathrm{~N}(\mathrm{Me})_{2 .}{ }^{12,13}$

$(R)$-2,3-Dihydro-2,5-dimethyl-1,5-benzothiazepin-4(5H)-one $[(R)-15]$ was prepared by the reaction of $(S)$ - $\beta$-butyrolactone (14) and $o$ - $(N$-methylamino)thiophenol (13) without isolation of the appropriate carboxylic acid intermediate (Scheme 4). ${ }^{14}$ However, this procedure has not hitherto been utilized for the synthesis of related optically active 2,3-dihydro-1,5-benzothiazepin$4(5 H)$-ones.<smiles>CNc1ccccc1S</smiles>

13<smiles>C[C@@H]1CC(=O)O1</smiles>

14

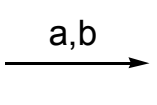

Scheme 4. (a)iPrOH, NaH, 20 min; (b) $\mathrm{DCC}, \mathrm{CH}_{2} \mathrm{Cl}_{2}, 20{ }^{\circ} \mathrm{C}$. ${ }^{14}$<smiles>CC1CC(=O)N(C)c2ccccc2S1</smiles>

$(R)-15$ 


\section{Synthesis of Optically Active 3-Alkyl-2,3-dihydro-1,5-benzothiazepin- $4(5 H)$-ones}

The first representative of optically active 3-alkyl-2,3-dihydro-1,5-benzothiazepin-4(5H)-ones was synthesized by Ohno et al. ${ }^{15,16} 2$-Aminothiophenol (1) was allowed to react with diethyl benzylidenemalonate (16) to obtain aminocarboxylic acid derivative 17 ring closure of which afforded 2,3-dihydro-3-(ethoxycarbonyl)-2-phenyl-1,5-benzothiazepin-4(5H)-one (18).<smiles>Nc1ccccc1S</smiles>

1<smiles>O=C1Nc2ccccc2SC(c2ccccc2)C1CO</smiles>

19<smiles>O=C1Nc2ccccc2SC(c2ccccc2)C1CCl</smiles>

20<smiles>CCOC(=O)C(=Cc1ccccc1)C(=O)OCC</smiles>

16
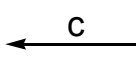

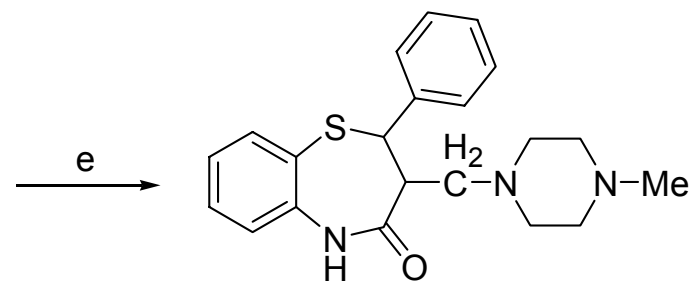<smiles>CCOC(=O)C(C(=O)OCC)C(Sc1ccccc1N)c1ccccc1</smiles><smiles>CCOC(=O)C1C(=O)Nc2ccccc2S(=C[In])C1c1ccccc1</smiles>

18

cis/trans-21<smiles>CN1CCN(CC2C(=O)Nc3ccccc3S[C@H]2c2ccccc2)CC1</smiles>

BTM-1086

Scheme 5. (a) $\mathrm{iPrOH}$; (b) $\mathrm{Et}_{3} \mathrm{~N} . \mathrm{HCl}, 180^{\circ} \mathrm{C}, 3 \mathrm{~h}$; (c) $\mathrm{LiAlH}_{4}$; (d) $\mathrm{SOCl}_{2}$, pyridine, benzene; (e) $N$-methylpiperazine. ${ }^{15,16}$

Compound 18 was then converted into 3-hydroxymethyl derivative 19 on reduction with $\mathrm{LiAlH}_{4}$. The hydroxy group was replaced by a chlorine atom and compound $\mathbf{2 0}$ was obtained 
which was reacted with $N$-methylpiperazine to yield a cis/trans mixture of 2,3-dihydro-3-[(4methylpiperazinyl)methyl]-2-phenyl-1,5-benzothiazepin-4(5H)-one (21) (Scheme 5). The diastereomers were then separated and the cis-21 was optically resolved with tartaric acid to afford (-)-cis-2,3-dihydro-3-[(4-methylpiperazinyl)methyl]-2-phenyl-1,5-benzothiazepin-4(5H)one as an optically pure substance. Its hydrochloride (BTM-1086) showed antiulcer and gastric secretary effects. ${ }^{16,17}$ It is worth mentioning that no data are available concerning the elucidation of the stereochemistry of 1,5-benzothiazepines 18-21.

\section{Synthesis and Bioactivities of Optically Active 3-Amino-2,3-dihydro-1,5- benzothiazepin-4(5H)-ones}

Optically active 3-amino-2,3-dihydro-1,5-benzothiazepin-4-(5H)-ones are especially useful substances in the drug research. One of their important effects is the angiotensin converting enzyme (ACE) inhibitory activity. The angiotensin converting enzyme (ACE) is a dipeptidyl carboxypeptidase catalyzing the hydrolysis of the decapeptide angiotensin I to the octapeptide angiotensin II. This octapeptide is a known vasoconstrictor promoting the release of the aldosterone. As a result, the ACE raises the blood pressure and, therefore, several ACE inhibitors are used to treat the hypertension and congestive heart failure. ${ }^{18}$ For this reason, a wide variety of ACE inhibitors have been synthesized and tested. In this review, we discuss only the optically active 3-amino-2,3-dihydro-1,5-benzothiazepine type ACE inhibitors.

The first representative of the optically active 3-amino-2,3-dihydro-1,5-benzothiazepin$4(5 H)$-ones was synthesized by Slade et al. ${ }^{19}$ Source of the chirality was the L-cysteine as a natural amino acid used as building block. $o$-Fluoronitrobenzene (22) was reacted with $\mathrm{N}$-acetylL-cysteine (23) to afford nitrocarboxylic acid $\mathbf{2 4}$ subsequent deacetylation of which gave $(S)$ - $(o$ nitrophenyl)-L-cysteine (25). Compound 25 was reacted with benzyl chloroformate to obtain $(S)$ (o-nitrophenyl)- $N$-(carbobenzyloxy)-L-cysteine (26) reduction of which provided $(S)-(o$ aminophenyl)- $N$-(carbobenzyloxy)-L-cysteine (27). Ring closure of 27 yielded 3(R)[(carbobenzyloxy)amino]-2,3-dihydro-1,5-benzothiazepin-4(5H)-one (28). Deprotection of the amino group gave the target 3(R)-amino-2,3-dihydro-1,5-benzothiazepin-4(5H)-one (29) (Scheme 6). ${ }^{19}$ 
<smiles>O=[N+]([O-])c1ccccc1F</smiles>

22

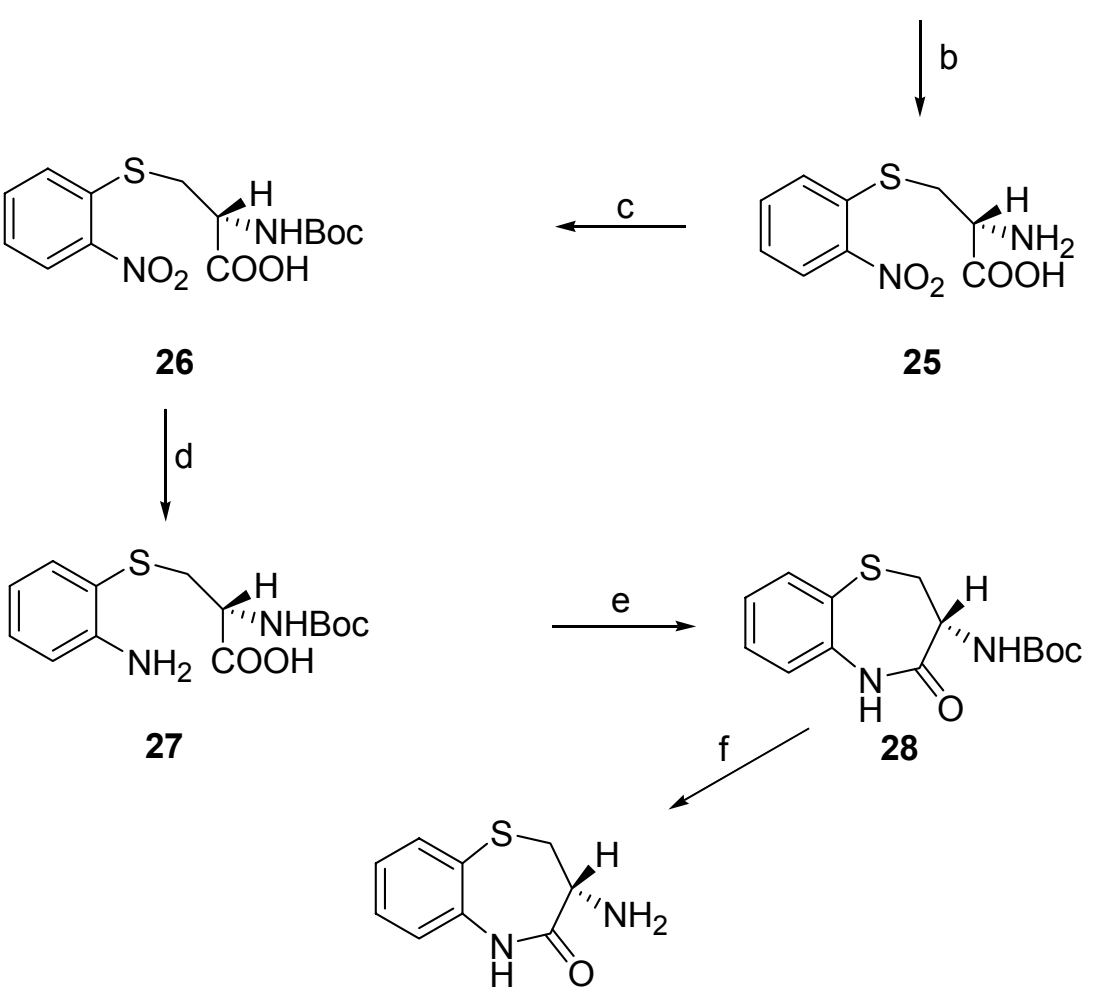

29

Scheme 6. (a) $\mathrm{NaHCO}_{3}, \mathrm{EtOH}$; (b) $\mathrm{H}_{2} \mathrm{SO}_{4}, \mathrm{H}_{2} \mathrm{O}$; (c) benzyl chloroformate, $\mathrm{NaOH}, \mathrm{H}_{2} \mathrm{O}$; (d) $\mathrm{NH}_{4} \mathrm{Cl}, \mathrm{MeOH}$, Zn dust; (e) DMF, carbodiimide; (f) $\mathrm{HBr}, \mathrm{AcOH}^{19}$

The 3(R)-[(carbobenzyloxy)amino]-2,3-dihydro-1,5-benzothiazepin-4(5H)-one (28) was further functionalized to afford ACE inhibitor 1,5-benzothiazepine derivatives $\mathbf{3 0}$ and $\mathbf{3 1}$ (Figure 1)..$^{20-22}$<smiles>O=C(O)CN1C(=O)[C@H](NC(CCc2ccccc2)C(=O)O)CSc2ccccc21</smiles>

30

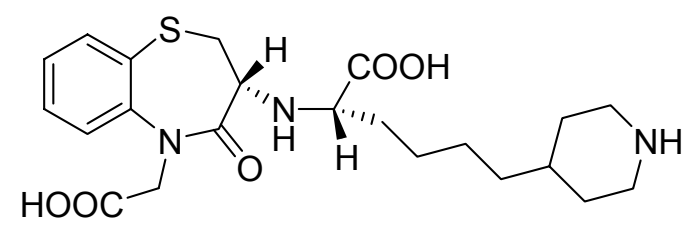

31

Figure 1. New ACE inhibitors. ${ }^{20-22}$ 
Amblard et al. ${ }^{23,24}$ synthesized 3(S)-amino-2,3-dihydro-1,5-benzothiazepin-4(5H)-ones (36) similarly to the reaction sequence described for the synthesis of the 3(R)-amino-2,3-dihydro-1,5benzothiazepin-4(5H)-one (29) ${ }^{19}$ using D-cysteine instead of L-cysteine as the source of chirality. $o$-Fluoronitrobenzenes 32 were allowed to react with Boc-D-cysteine (33) to afford nitrocarboxylic acid derivatives $\mathbf{3 4}$ which yielded aminocarboxylic acids $\mathbf{3 5}$ on reduction with $\mathrm{Zn}$ dust. Ring closure of compounds 35 gave 3(S)-[(carbobenzyloxy)amino]-2,3-dihydro-1,5benzothiazepin-4(H)-ones 36. Alkylation of $\mathbf{3 6}$ with ethyl bromoacetate gave 5[(ethyoxycarbonyl)methyl]-1,5-benzothiazepines 37. Saponification of these ethyl esters provided the target carboxylic acids 38 (Scheme 7 ). ${ }^{23}$<smiles>O=[N+]([O-])C1=C(F)C=C[R]C=C1</smiles>

32<smiles>CC(C)(C)N[C@@H](CS)C(=O)O</smiles>

33

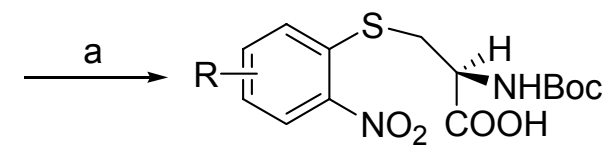

34

b

$\checkmark$

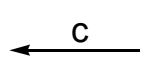<smiles>[R][R]N[C@H](CSc1ccccc1N)C(=O)O</smiles>

35

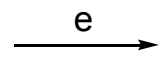

Scheme 7. (a) $\mathrm{NaHCO}_{3}, \mathrm{EtOH}, \mathrm{H}_{2} \mathrm{O}$; (b) $\mathrm{NH}_{4} \mathrm{Cl}, \mathrm{MeOH}, \mathrm{Zn}$ dust; (c) $\mathrm{NaHCO}_{3}, \mathrm{BOP}, \mathrm{DMF}$; (d) $\mathrm{BrCH}_{2} \mathrm{COOEt}, \mathrm{KOH}, \mathrm{n}-\mathrm{Bu}_{4} \mathrm{NBr}$, THF; (e) $\mathrm{NaOH}, \mathrm{EtOH}^{23}$

Robl et al. ${ }^{25,26}$ synthesized optically active 3(R)-amino-2,3-dihydro-1,5-benzothiazepin4(5H)-ones 40 and 41 starting from 3(R)-amino-2,3-dihydro-5-[(ethoxycarbonyl)methyl]-2,3dihydro-1,5-benzothiazepin-4(5H)-one (39) as outlined in Scheme 8. Compounds 40 and 41 were found to possess high in vitro and in vivo inhibitory activity against ACE and neutral endopeptidase (NEP).

Human leukocyte elastase (HLE) inhibitor 3(R)-amino-2,3-dihydro-1,5-benzothiazepin4(5H)-one derivative 43 was synthesized by Skiles et al. ${ }^{27}$ starting from $3(R)$-amino-5(carboxymethyl)-2,3-dihydro-1,5-benzothiazepin-4(5H)-one (42) (Scheme 9). 

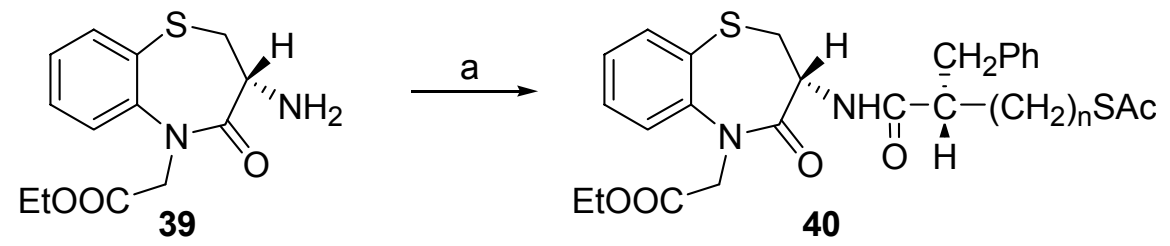

n: 0,1

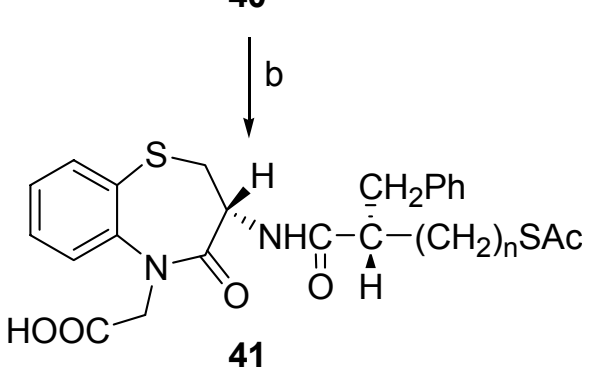

Scheme 8. (a) acylation; (b) $\mathrm{NaOH}, \mathrm{EtOH}^{25,26}$<smiles>O=C(O)CN1C(=O)[C@H](NC(=O)OCc2ccccc2)CSc2ccccc21</smiles><smiles>CC(C)C(C)OC(=O)N[C@H]1CSc2ccccc2N1CC(=O)OCc1ccccc1</smiles>

43

Scheme 9. (a) amine, CDI, THF. ${ }^{27}$

Kawanishi et al. ${ }^{28}$ synthesized a wide variety of 3(S)-amino-2,3-dihydro-1,5-benzothiazepin4(5H)-ones 45 and 46 starting from 2,3-dihydro-3(S)-phthalimido-1,5-benzothiazepin-4(5H)-one (44) (Scheme 10).<smiles>CC(C)(C)[C@H]1CSc2ccccc2NC1=O</smiles><smiles>C[13CH][13CH3]</smiles><smiles>[R1]OC(=O)NCC(C)(C)OC</smiles><smiles>[R1]c1cccc(NC(=O)[NH2+][C@H]2CSc3ccccc3NC2=O)c1</smiles>

45

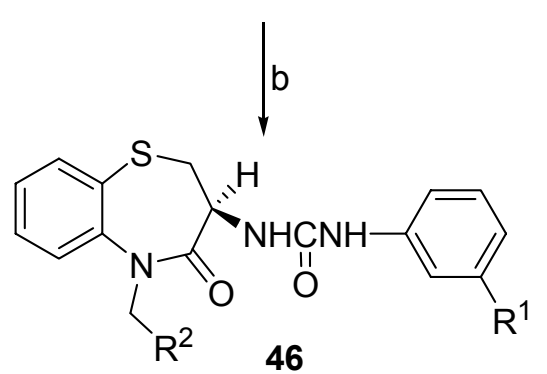

Scheme 10. (a) deprotection, isocyanate; (b) alkylation. ${ }^{28}$ 
Solid-phase synthesis of optically active 3-amino-2,3-dihydro-1,5-benzothiazepin-4(5H)ones, using cysteine derivatives as building blocks, has also been described in the literature. ${ }^{29}$

Amblard et al. ${ }^{30-33}$ synthesized bradykinin agonist optically active 3-amino-2,3-dihydro-1,5benzothiazepin-4(5H)-ones. Some representatives of such benzothiazepines (cf. 47 and 48) are shown in Figure 2.

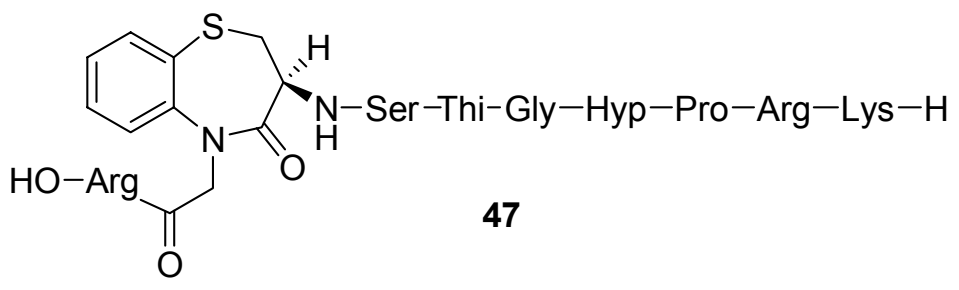

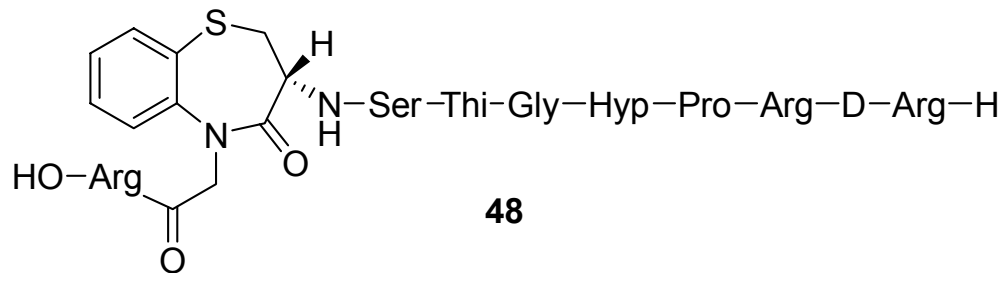

Figure 2. Examples of bradykinin agonist benzothiazepines. ${ }^{30-33}$

\section{Synthesis and Bioactivities of Optically Active 2,3-Dihydro-3-hydroxy-1,5- benzothiazepin-4(5H)-ones}

Kugita et al. ${ }^{34-36}$ published the first synthesis of 2-aryl-2,3-dihydro-3-hydroxy-1,5benzothiazepin-4(5H)-ones in 1970. 2-Nitrothiophenol (49) was reacted with phenylglycidic esters 50 to afford the appropriate nitrocarboxylic acid esters 51 which were reduced to aminocarboxylic acid esters 52. Compounds 52 were saponified to obtain the free carboxylic acids 53 ring closure of which provided the target 2-aryl-2,3-dihydro-3-hydroxy-1,5benzothiazepin-4(5H)-ones 54 as diastereomeric mixtures (Scheme 11). As a result of further developments, depending on the reaction conditions of the ring opening of the phenylglycidic esters, either cis- or trans-2-aryl-2,3-dihydro-3-hydroxy-1,5-benzothiazepin-4 $(H)$-ones were obtained as single diastereomers. 


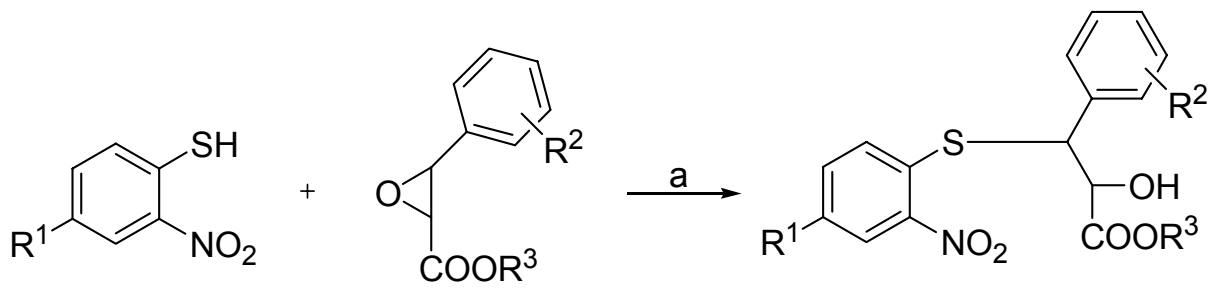

49

50

51<smiles>[R]OC(=O)C(O)C(Sc1ccc([R])cc1N)c1cccc([R2])c1</smiles>

53

52<smiles>[R2]c1cccc(C2Sc3ccc([R])cc3NC(=O)C2O)c1</smiles>

$\mathrm{R}^{1}: \mathrm{H}, \mathrm{Cl}$

$\mathrm{R}^{2}$ : alkoxy, halogen

$\mathrm{R}^{3}$ : alkyl

54

Scheme 11. (a) $\mathrm{NaHCO}_{3}$, EtOH; (b) $\mathrm{FeSO}_{4} \cdot \mathrm{H}_{2} \mathrm{O}$, EtOH; (c) $\mathrm{NaOH}$, EtOH; (d) xylene, reflux. ${ }^{34}$

It has been proven that numerous derivatives of the 2-aryl-2,3-dihydro-3-hydroxy-1,5benzothiazepin-4(5H)-ones are useful seven-membered heterocyclic compounds in the drug research. Their $\mathrm{N}$-alkylated and 3-O-acylated derivatives 55 and 56 were synthesized and tested in the early stage of the research of these benzothiazepines. ${ }^{36-43}$ Some general chemical transformations providing such benzothiazepines are illustrated in Scheme 12.

Among benzothiazepines shown in Scheme 12, the 3-acetoxy-2,3-dihydro-5-[2(dimethylamino)ethyl]-2-(4-methoxyphenyl)-1,5-benzothiazepin-4(5H)-one (diltiazem) was found to be an especially active substance with its coronary vasodilatory, ${ }^{38-40}$ antiarrythmic ${ }^{41}$ and haemodynamic $^{42}$ effects. The diltiazem can exist in four diastereomeric forms. Its has also turned out that the (+)-diltiazem, viz. the 3(S)-acetoxy-2,3-dihydro-5-[2-(dimethylamino)-ethyl]-2(S)-(4methoxyphenyl)-1,5-benzothiazepin-4(5H)-one is the most effective isomer. Its effectiveness stimulated the efforts to develop various synthetic protocols for its preparation. These efforts were further supported by the fact that nowadays only optically pure active ingredients are allowed to use for the production and sale of medicines. Owing to the huge amount of literaterature data, in this paragraph we included only the most adequate selected examples to 
illustrate some procedures used for this purpose which means that not all papers published on this topic are included and discussed.

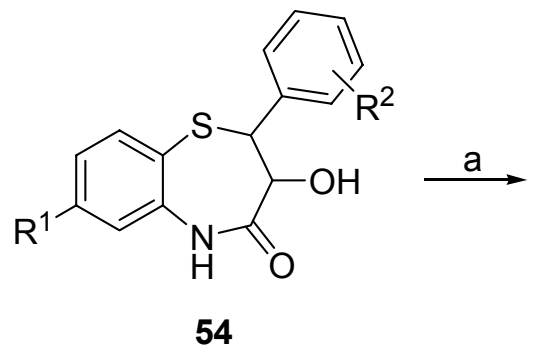

$\mathrm{R}^{1}: \mathrm{H}, \mathrm{Cl}$

$\mathrm{R}^{2}$ : alkoxy, halogen

$\mathrm{R}^{3}$ : alkyl, $\mathrm{Ph}$

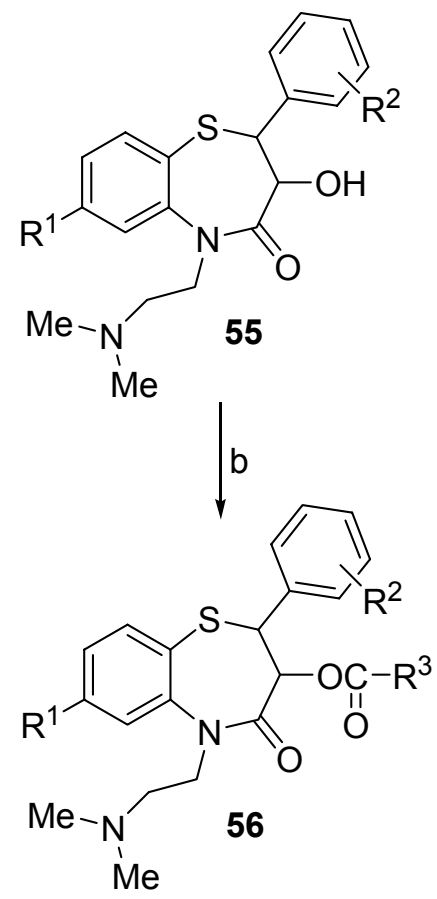

Scheme 12. (a) $\mathrm{ClCH}_{2} \mathrm{CH}_{2} \mathrm{NMe}_{2}$, dioxane, $\mathrm{NaH}$; (b) pyridine, $\mathrm{AcCl}{ }^{36}$

The first synthesis of $(+)$-diltiazem was achieved by Inoue et al. ${ }^{44}$ in 1973 and its $(2 S, 3 S)$ absolute configuration was determined by X-ray diffraction analysis. Diastereomeric salt formation of cis-3-(2-aminophenylthio)-2-hydroxy-3-(4-methoxyphenyl)propionic acid (57) with various optically active amines followed by the liberation of the optically active aminocarboxylic acids $(2 S, 3 S)-57$ and $(2 R, 3 R)-57$. Ring closure of these optically active intermediates provided the optically active benzothiazepines $(2 S, 3 S)-\mathbf{5 8}$ and $(2 R, 3 R)-\mathbf{5 8}$. Further chemical transformations of the $\mathbf{5 8}$ yielded the target (+)- and (-)-diltiazem 59 (Scheme 13).

A wide variety of synthetic procedures based on the preparation of optically active carboxylic acid intermediates have been worked out. Selected examples of these procedures are included in this paragraph. The key starting materials of the synthesis are the 3-phenylglycidates. Utilization of optically active 3-phenylglycidates have been published by several research groups. $^{45-48}$ Racemic nitrocarboxylic acid $^{49}$ or aminocarboxylic acid ${ }^{50}$ intermediates were optically resolved via distereomeric salt formation. Optically active intermediates used for the synthesis of the diltiazem have also been prepared by enzyme-catalyzed resolution. ${ }^{51-54}$ In some cases, either the aminocarboxylic acid intermediates or the racemic 1,5-benzothiazepine derivatives were optically resolved to yield the optically active target compounds. ${ }^{55}$ 


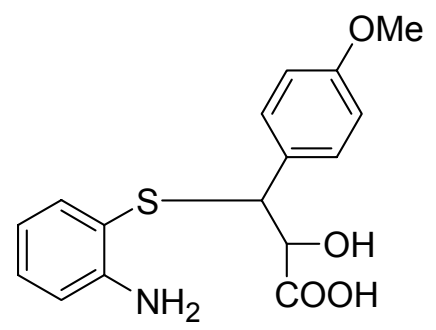

(士)-57

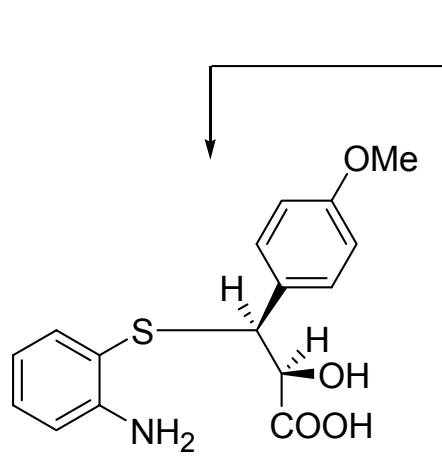

(2S,3S)-57<smiles>COc1ccc([C@H]2Sc3ccccc3NC(=O)[C@H]2O)cc1</smiles>

(2S,3S)-58<smiles>CNCCN1C(=O)[C@@H](OC(C)=O)[C@@H](c2ccc(Cl)cc2)[C@@H](c2ccc(OC)cc2)Sc2ccccc21</smiles>

(2S,3S)-59

(+)-Diltiazem<smiles>COc1ccc([C@H](Sc2ccccc2N)[C@H](O)C(=O)O)cc1</smiles>

(2R,3R)-57<smiles>COc1ccc([C@H]2Sc3ccccc3NC(=O)[C@H]2O)cc1</smiles>

(2R,3R)-58<smiles>CNCCN1C(=O)[C@@H](OC(C)=O)[C@@H](c2ccccc2)[C@@H](c2ccc(OC)cc2)Sc2ccccc21</smiles>

(2R,3R)-59

(-)-Diltiazem

Scheme 13. (a) optically active amine, $\mathrm{HCl}$; (b) xylene, reflux; (c) $\mathrm{ClCH}_{2} \mathrm{CH}_{2} \mathrm{NMe}_{2}$, dioxane, $\mathrm{NaH}$; (d) pyridine, $\mathrm{AcCl}^{44}$ 
Optically active methyl $(2 R, 3 S)-3-(4-m e t h o x y p h e n y l) g l y c i d a t e ~[(-)-61]$ was obtained by the transesterification of (-)-(2R,3S)-3-(4-methoxyphenyl)glycidic acid 4-chloro-3-(methylphenyl) ester [(-)-60] obtained by the optical resolution of $( \pm)-\mathbf{6 0}$ by preferred crystallization in DMF. ${ }^{56}$

Chemical transformations of compound (-)-61 outlined in Scheme 14 provided (+)-diltiazem $[(+)-59]$. Methyl (2R,3S)-3-(4-methoxyphenyl)glycidate [(-)-61] has also been prepared starting from 4-methoxyacetophenone via dynamic kinetic resolution. ${ }^{57}$ In special cases, optically active aminocarboxylic amides were used as intermediates for the preparation of $(+)$-diltiazem. ${ }^{58,59}$

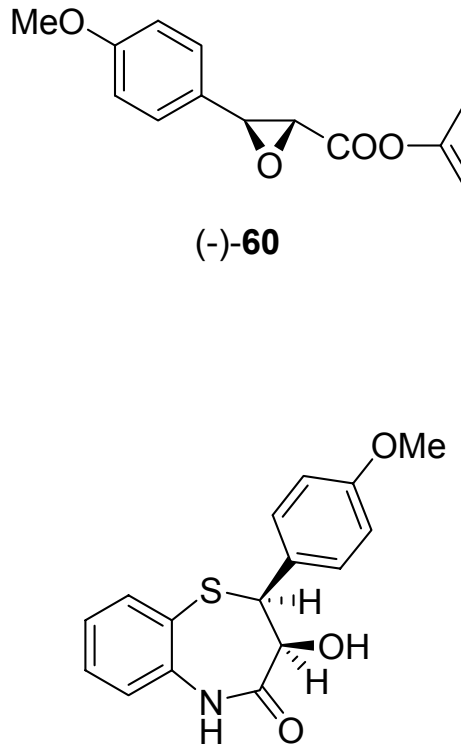

$(2 S, 3 S)-58$

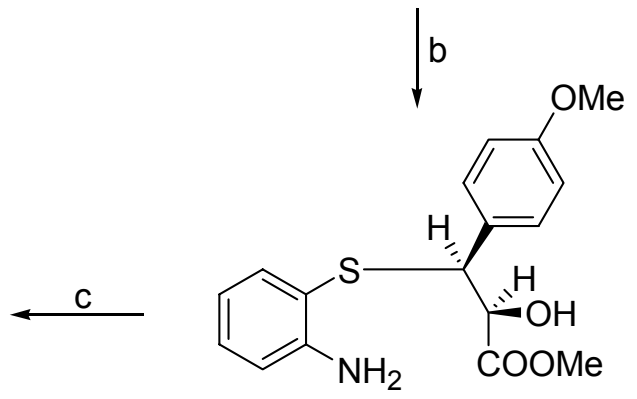

$(2 S, 3 S)-62$<smiles>COc1ccc([C@H]2Sc3ccccc3N(CCN(C)C)C(=O)[C@@H]2OC(C)=O)cc1</smiles>

$(2 S, 3 S)-59$

$(+)$-Diltiazem

Scheme 14. (a) $\mathrm{MeOH}, \mathrm{NaOMe}$; (b) 2-aminothiophenol; (c) chlorobenzene, methanesulfonic acid, reflux for $1 \mathrm{~h}$; (d) $\mathrm{ClCH}_{2} \mathrm{CH}_{2} \mathrm{NMe}_{2}$, dioxane, $\mathrm{NaH}$, pyridine, $\mathrm{AcCl}^{57}$ 
Starting from the appropriate optically active aminocarboxylic acid esters 62 and $63(2 S, 3 S)$ and $(2 R, 3 R)$-isomers of the 2,3-dihydro-3-hydroxy-2-(4-methoxyphenyl)-1,5-benzothiazepin$4(5 H)$-one (58) were prepared ${ }^{60}$ (Scheme 15).

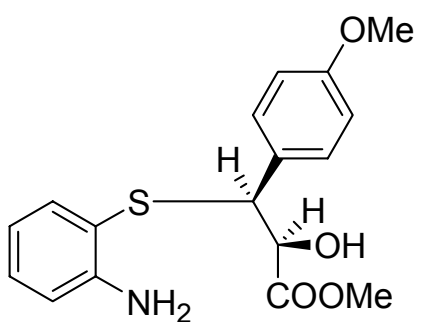

62

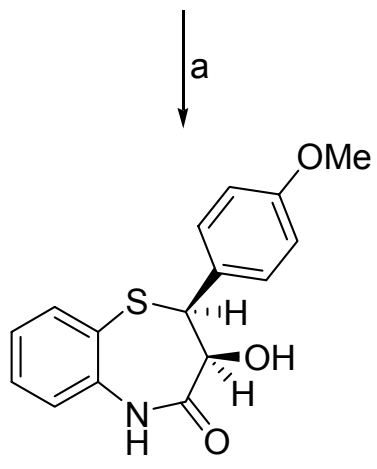

$(2 S, 3 S)-58$

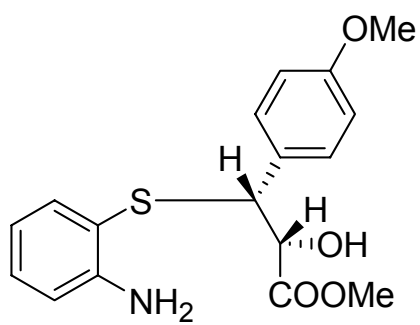

63

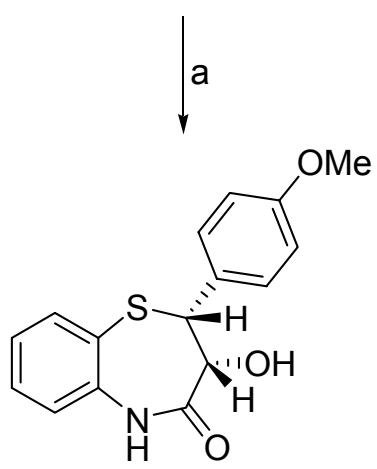

$(2 R, 3 R)-58$

Scheme 15. (a) p-TSA, xylene, reflux, 3 h. ${ }^{60}$

Microwave-assisted synthesis of cis- and trans-2,3-dihydro-3-hydroxy-2-(4-methoxyphenyl)1,5-benzothiazepin-4(5H)-one $(\mathbf{5 8})$ has also been described ${ }^{61}$ in the literature. However, this publication is the sole example for the utilization of this technique.

Asymmetric reduction of 2-(4-methoxyphenyl)-1,5-benzothiazepin-3,4-(2H,5H)-dione (64) with $\mathrm{NaBH}_{4}$ in combination with optically active $\alpha$-amino acids gave 2,3-dihydro-3(S)-hydroxy2(S)-(4-methoxyphenyl)-1,5-benzothiazepin-4(5H)-one (58) (Scheme 16). ${ }^{62}$<smiles>COc1ccc(C2Sc3ccccc3NC(=O)C2=O)cc1</smiles>

64<smiles>COc1ccc([C@H]2Sc3ccccc3NC(=O)[C@H]2O)cc1</smiles>

$(2 S, 3 S)-58$

Scheme 16. (a) $\mathrm{NaBH}_{4}$, L-proline. ${ }^{62}$ 
Optical purity, conformation and absolute configuration of these optically active 1,5benzothiazepines and their optically active intermediates have been elucidated by NMR spectroscopic measurements, X-ray diffraction analysis and circular dichroism (CD) spectroscopy. ${ }^{49,63-66}$

Several metabolites of the diltiazem have been prepared and were found to possess various bioactivities. $^{43,67-73}$ Biological and pharmacological activities of these benzothiazepines have been studied in numerous research laboratories and pharmaceutical companies. Their most important effects are antihypertensive, cardiovascular, spasmolytic, calcium channel blocking and antithrombotic activities. On all these bases, the 2,3-dihydro-3-hydroxy-1,5-benzothiazepin$4(5 H)$-oes are the most valuable benzothiazepine type compounds in the drug research.

\section{Miscellaneous}

In this closing paragraph, a few interesting representatives of the optically active 1,5benzothiazepines are included. In special cases, optically active 1,5-benzothiazepines were synthesized by the reaction of optically active natural products or their semisynthetic derivatives with 2-aminothiophenol (1). Tronchet and Gentile $^{74}$ reacted the $\alpha, \beta$-unsaturated ketone 65 derived from sugar with 2-aminothiophenol (1) to obtain a spirobenzothiazepine type compound 66 (Scheme 17). In the case of this optically active 1,5-benzothiazepine, the source of the chirality was the sugar used as building block.
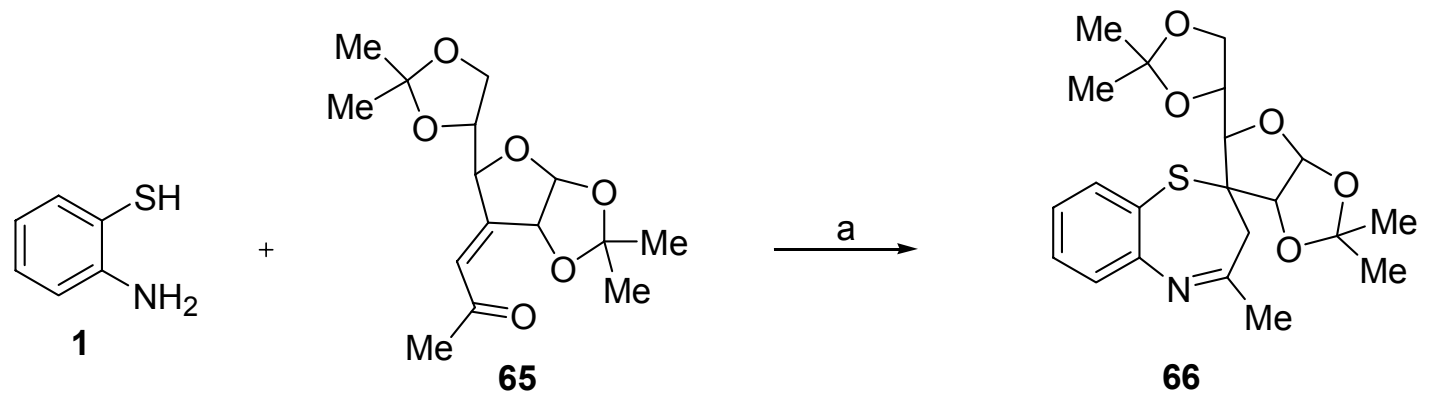

Scheme 17. (a) $\mathrm{MeOH}, \mathrm{MgSO}_{4}, 60^{\circ} \mathrm{C}, 24 \mathrm{~h}^{74}$

Mushfiq et al. ${ }^{75-77}$ synthesized optically active 1,5-benzothiazepines condensed with a steroid skeleton. Steroid derivatives $\mathbf{6 7}$ bearing an $\alpha, \beta$-unsaturated ketone unit were allowed to react with 2-aminothiophenol (1) to afford the benzothiazepine derivatives 68 (Scheme 18). In these cases, the source of the chirality was the steroid building block. 


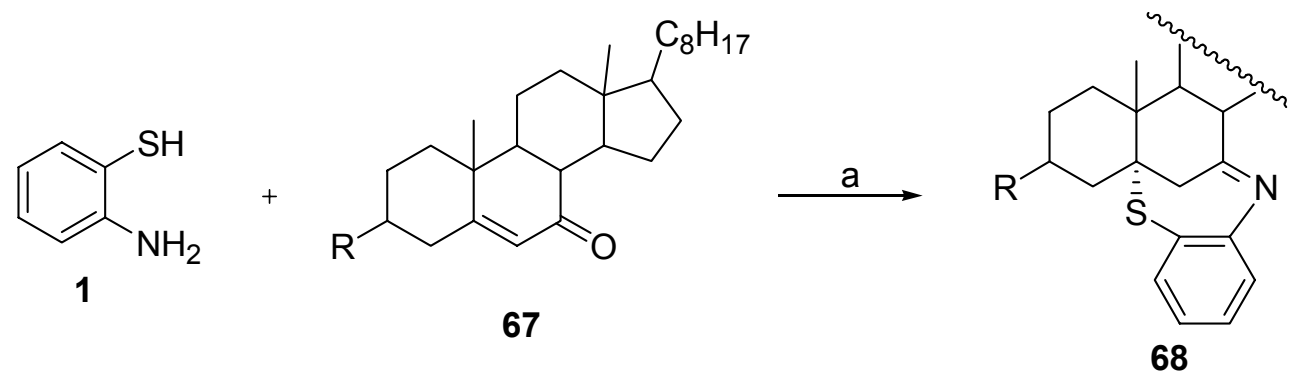

$\mathrm{R}: \mathrm{H}, \mathrm{OCOMe}, \mathrm{Cl}$

Scheme 18. (a) $\mathrm{MeOH}, \mathrm{ccHCl}^{76}$

\section{Conclusions}

Chemistry of well known groups of optically active 1,5-benzothiazepines are summarized in this review article. The most important procedures used for their synthesis are discussed with the help of adequate examples. Their most valuable bioactivities are mentioned in brief. Selected original papers included in the References will help the reader to find the original information concerning a special 1,5-benzothiazepine derivative.

\section{Acknowledgements}

The present study was sponsored by the Hungarian National Research Fund (Grant No. OTKA T049468) for which our gratitude is expressed.

\section{References}

1. Lévai, A. Trends Heterocycl. Chem. 1995, 4, 51.

2. Mills, W. H.; Whithworth, J. B. J. Chem. Soc. 1927, 2738.

3. Krapcho, J.; Turk, C. F.; Piala, J. J. J. Med. Chem. 1968, 11, 361.

4. Puzicha, G.; Lévai, A.; Szilágyi, L. Monatsh. Chem. 1988, 119, 933.

5. Lévai, A.; Puzicha, G. Synth. Commun. 1985, 15, 623.

6. $\quad$ Duddeck, H.; Kaiser, M.; Lévai, A. Liebigs Ann. Chem. 1985, 869.

7. Ciechanowicz-Rutkowska, M.; Grochowski, J.; Lévai, A.; Puzicha, G.; Serda, P.; Snatzke, G. Monatsh. Chem. 1989, 120, 981.

8. Puzicha, G.; Lévai, A.; Snatzke, G. Monatsh. Chem. 1990, 121, 293.

9. Lévai, A. J. Heterocycl. Chem. 2000, 37, 199.

10. Lévai, A. Acta Chim. Acad. Sci. Hung. 1980, 104, 385. 
11. Lévai, A. Acta Chim. Acad. Sci. Hung. 1981, 107, 361.

12. Dike, S. Y.; Ner, D. H.; Kumar, A. Synlett 1991, 443.

13. Dike, S. Y.; Ner, D. H.; Kumar, A. Bioorg. Med. Chem. Lett. 1991, 1, 383.

14. Breitschuh, R.; Seebach, D. Synthesis 1992, 1170.

15. Ohno, S.; Izumi, K.; Mizukoshi, K.; Kato, K.; Hori, M. Chem. Pharm. Bull. 1983, 31, 1780.

16. Ohno, S.; Mizukoshi, K.; Izumi, K.; Kato, K.; Hori, M. Chem. Pharm. Bull. 1988, 36, 551.

17. Yamamoto, H.; Asai, H. Chem. Pharm. Bull. 1986, 34, 3844.

18. Chatterjee, K. Heart Dis. Stroke 1992, 1, 128.

19. Slade, J.; Stanton, J. L.; Bed-David, D.; Mazzenga, G. C. J. Med. Chem. 1985, $28,1517$.

20. Itoh, K.; Kori, M.; Inada, Y.; Nishikawa, K.; Kawamatsu, Y.; Sugihara, H. Chem. Pharm. Bull. 1986, 34, 1128, 2078, 3747.

21. Kori, M.; Itoh, K.; Sugihara, H. Chem. Pharm. Bull. 1987, 35, 2319.

22. Inada, Y.; Itoh, K.; Kamiya, K.; Sugihara, H.; Nishikawa, K. Japan J. Pharmacol. 1988, 47, 135.

23. Amblard, M.; Calmés, M.; Roques, V.; Tabet, S.; Loffet, A.; Martinez, J. Org. Prep. Proced. Int. 2002, 34, 405.

24. Amblard, M.; Raynal, N.; Averlant-Petit, M. C.; Didierjean, C.; Calmés, M.; Fabre, O.; Aubry, A.; Marraud, M.; Martinez, J. Tetrahedron Lett. 2005, 46, 3733.

25. Robl, J. A.; Simpkins, L. M.; Stevenson, J.; Sun, C. Q.; Murugesan, N.; Barrish, J. C.; Asaad, M. M.; Bird, J. E.; Schaeffer, T. R.; Trippodo, N. C.; Petrillo, E. W.; Karanewsky, D. S. Bioorg. Med. Chem. Lett. 1994, 4, 1789.

26. Das, J.; Robl, J. A.; Reid, J. A.; Sun, C. Q.; Misra, R. N.; Brown, B. R.; Ryono, D. E.; Asaad, M. M.; Bird, J. E.; Trippodo, N. C.; Petrillo, E. W.; Karanewsky, D. S. Bioorg. Med. Chem. Lett. 1994, 4, 2193.

27. Skiles, J. W.; Sorcek, R.; Jacober, S.; Miao, C.; Mui, P. W.; McNeil, D.; Rosenthal, A. S. Bioorg. Med. Chem. Lett. 1993, 3, 773.

28. Kawanishi, Y.; Ishihara, S.; Tsushima, T.; Seno, K.; Hagishita, S.; Ishikawa, M.; Ishihara, Y. Bioorg. Med. Chem. 1997, 5, 1411.

29. Schwarz, M. K.; Tumelty, D.; Gallop, M. A. J. Org. Chem. 1999, 64, 2219.

30. Amblard, M.; Daffix, I.; Bedos, P.; Bergé, G.; Pruneau, D.; Paquet, J. L.; Luccarini, J. M.; Bélichard, P.; Dodey, P.; Martinez, J. J. Med. Chem. 1999, 42, 4185.

31. Amblard, M.; Daffix, I.; Bergé, G.; Calmés, M.; Dodey, P.; Pruneau, D.; Paquet, J. L.; Luccarini, J. M.; Bélichard, P.; Martinez, J. J. Med. Chem. 1999, 42, 4193.

32. Amblard, M.; Bedos, P.; Olivier, C.; Daffix, I.; Luccarini, J. M.; Dodey, P.; Pruneau, D.; Paquet, J. L.; Martinez, J. J. Med. Chem. 2000, 43, 2382.

33. Bedos, P.; Amblard, M.; Subra, G.; Dodey, P.; Luccarini, J. M.; Paquet, J. L.; Pruneau, D.; Aumelas, A.; Martinez, J. J. Med. Chem. 2000, 43, 2387.

34. Kugita, H.; Inoue, H.; Ikezaki, M.; Takeo, S. Chem. Pharm. Bull. 1970, 18, 2028.

35. Kugita, H.; Inoue, H.; Ikezaki, M.; Konda, M.; Takeo, S. Chem. Pharm. Bull. 1970, 18, 2384. 
36. Kugita, H.; Inoue, H.; Ikezaki, M.; Konda, M.; Takeo, S. Chem. Pharm. Bull. 1971, 19, 595.

37. Sakuma, M.; Yoshikawa, M.; Sato, Y. Chem. Pharm. Bull. 1971, 19, 995.

38. Sato, M.; Nagao, T.; Yamaguchi, I.; Nakajima, H.; Kiyomoto, A. Arzneim.-Forsch. (Drug Res.) 1971, 21, 1338.

39. Nagao, T.; Sato, M.; Nakajima, H. Japan J. Pharm. 1972, 22, 1.

40. Nagao, T.; Sato, M.; Nakajima, H.; Kiyomoto, A. Chem. Pharm. Bull. 1973, 21, 92.

41. Yamada, K.; Shimamura, T.; Nakajima, H. Japan J. Pharmacol. 1973, 23, 321.

42. Kusukawa, R.; Kinoshita, M.; Shimono, Y.; Tomonaga, G.; Hoshino, T. Arzneim.-Forsch. (Drug Res.) 1977, 27, 878.

43. Miyazaki, M.; Iwakuma, T.; Tanaka, T. Chem. Pharm. Bull. 1978, 26, 2889.

44. Inoue, H.; Takeo, S.; Kawazu, M.; Kugita, H. Yakugaku Zasshi 1973, 93, 729.

45. Schwarz, A.; Madan, P. B.; Mohacsi, E.; O’Brien, J. P.; Todaro, L. J.; Coffen, D. L. J. Org. Chem. 1992, 57, 851.

46. Gizur, T.; Harsányi, K.; Fogassy, E. J. Prakt. Chem. 1994, 336, 628.

47. Yamada, S. I.; Tsujioka, I.; Shibatani, T.; Yoshioka, R. Chem. Pharm. Bull. 1999, 47, 146.

48. Imashiro, R.; Kuroda, T. Tetrahedron Lett. 2001, 42, 1313.

49. Senuma, M.; Shibazaki, M.; Nishimoto, S.; Shibata, K.; Okamura, K.; Date, T. Chem. Pharm. Bull. 1989, 37, 3204.

50. Das, J.; Floyd, D. M.; Kimball, S. D.; Duff, K. J.; Lago, M. W.; Krapcho, J.; White, R. E.; Ridgewell, R. E.; Obermeier, M. T.; Moreland, S.; McMullen, D.; Normandin, D.; Hedberg, S. A.; Schaeffer, T. R. J. Med. Chem. 1992, 35, 2610.

51. Kanerva, L. T.; Sundholm, O. (1993) J. Chem. Soc. Perkin Trans. 1 1993, 1385, 2407.

52. Inoue, H.; Matsuki, K.; Oh-Ishi, T. Chem. Pharm. Bull. 1993, 41, 1521.

53. Akita, H.; Umezawa, I.; Matsukura, H. Chem. Pharm. Bull. 1997, 45, 272.

54. Yamada, S. I.; Yoshioka, R.; Shibatani, T. Chem. Pharm. Bull. 1997, 45, 1922.

55. Inoue, H.; Konda, M.; Hashiyama, T.; Otsuka, H.; Watanabe, A.; Gaino, M.; Takahashi, K.; Date, T.; Okamura, K.; Takeda, M.; Narita, H.; Murata, S.; Odawara, A.; Sasaki, H.; Nagao, T. Chem. Pharm. Bull. 1997, 45, 1008.

56. Yamada, S. I.; Morimatsu, K.; Yoshioka, R.; Ozaki, Y.; Seko, H. Tetrahedron: Asymmetry 1998, 9, 1713.

57. Mordant, C.; Cano de Andrade, C.; Tonati, R.; Ratovelomanana-Vidal, V.; Ben Hassine, B.; Genét, J. P. Synthesis 2003, 2405.

58. Miyata, O.; Shinada, T.; Ninomiya, I.; Naito, T. Tetrahedron Lett. 1991, 32, 3519.

59. Miyata, O.; Shinada, T.; Ninomiya, I.; Naito, T. Tetrahedron 1997, 53, 2421.

60. Komiyama, T.; Takaguchi, Y.; Tsuboi, S. Heterocycles 2005, 66, 147.

61. Vega, J. A.; Cueto, S.; Ramos, A.; Vaquero, J. J.; Garcia-Navio, J. L.; Alvarez-Builla, J. Tetrahedron Lett. 1996, 37, 6413.

62. Yamada, S. I.; Mori, Y.; Morimatsu, K.; Ishizu, Y.; Ozaki, Y.; Yoshioka, R.; Nakatani, T.; Seko, H. J. Org. Chem. 1996, 61, 8586. 
63. Kojic-Prodic, B.; Ruzic-Toros, Z.; Sunjic, V.; Decorte, E.; Moimas, F. Helv. Chim. Acta 1984, 67, 916.

64. Glaser, R.; Sklarz, B. J. Chem. Soc. Perkin Trans. 2 1989, 1031.

65. Marthi, K.; Larsen, S., Ács, M.; Fogassy, E. Acta Chem. Scand. 1996, 50, 899.

66. Marthi, K.; Larsen, S.; Ács, M.; Jászay, Z.; Fogassy, E. Acta Chem. Scand. 1996, 50, 906.

67. Kendall, M. J.; Okopski, J. V. J. Clin. Hosp. Pharm. 1986, 11, 159.

68. Narita, H.; Murata, S.; Yabana, H.; Kikkawa, K.; Sugawara, Y.; Akimoto, Y.; Nagao, T. Arzneim.-Forsch. (Drug Res.) 1988, 38, 515.

69. Harada, T.; Morimoto, M.; Nagasawa, M.; Takamura, N.; Inoue, H.; Oh-Ishi, T.; Takeda, M. Chem. Pharm. Bull. 1992, 40, 1986.

70. Yanagisawa, H.; Fujimoto, K.; Shimoji, Y.; Kanazaki, T.; Mizutari, K.; Nishino, H.; Shiga, H.; Koike, H. Chem. Pharm. Bull. 1992, 40, 2055.

71. Li, R., Farmer, P. S., Xie, M.; Quilliam, M. A.; Pleasance, S.; Howlett, S. E.; Yeung, P. K. F. J. Med. Chem. 1992, 35, 3246.

72. Inoue, H.; Nakamura, S.; Otsuka, H.; Gaino, M.; Harada, T.; Matsuki, K.; Takeda, M. Chem. Pharm. Bull. 1994, 42, 167.

73. Kantoci, D.; Murray, Jr, E. D.; Quiggle, D. D.; Wechter, W. J. J. Med. Chem. 1996, $39,1196$.

74. Tronchet, J. M. J.; Gentile, B. Helv. Chim. Acta 1980, 63, 1779.

75. Mushfiq, M.; Iqbal, N. J. Chem. Research (S) 1987, 274.

76. Mushfiq, M.; Iqbal, N. J. Chem. Research (S) 1988, 254.

77. Mushfiq, M.; Mudgal, G. J. Chem. Research (S) 1992, 168. 


\section{Authors' biographies}

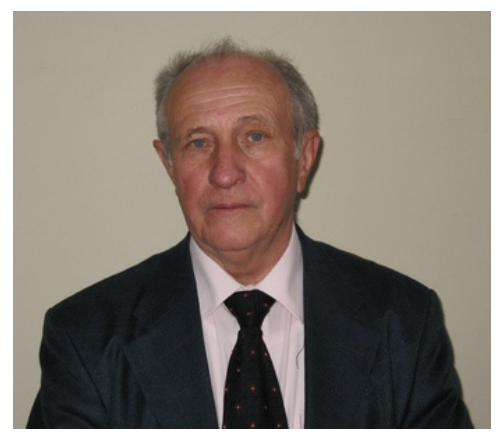

Albert Lévai obtained his Ph.D. degree in Organic Chemistry in 1974 and his Habilitation in 1998 from the Kossuth Lajos University of Debrecen (Hungary). He received the title of Doctor of the Hungarian Academy of Sciences in 2001. His research interests include the synthesis and stereochemistry of various groups of heterocyclic compounds, viz. benzopyrans, benzothiopyrans, pyrazolines, epoxides, benzothiazepines and benzoxazepines. He is full professor of the Department of Organic Chemistry of the University of Debrecen, Hungary.

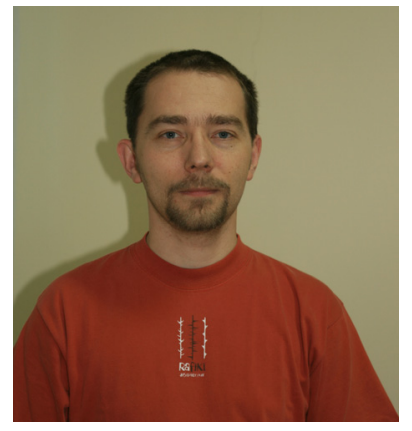

Attila Kiss-Szikszai obtained his Ph.D. degree in Organic Chemistry in 2005 from the University of Debrecen (Hungary). His research interests include the synthesis and stereochemistry of various groups of heterocyclic compounds such as benzo(hetera)cyclanones. He is research assistant of the Department of Organic Chemistry at the University of Debrecen, Hungary. 